\title{
KONSUMSI RUMPUT LAUT DAPAT MENGATASI ANEMIA KEHAMILAN
}

\section{Consumption of Seaweed can Overcome Anemia in Pregnancy}

\author{
Melly Damayanti ${ }^{1}$, Astri Yulia Sari Lubis ${ }^{2}$, Wahyu Eny Setyohari ${ }^{3}$ \\ ${ }^{123}$ Poltekkes Kemenkes Tanjungpinang, \\ Jl Arif Rahman Hakim No. 1 Kota Tanjungpinang, Provinsi Kepulauan Riau \\ apriyandimelly@gmail.com
}

\section{Riwayat Artikel \\ Diajukan: Januari 2020}

Diterima: Maret 2020

\section{Penulis Korespondensi:}

- Melly Damayanti

- Poltekkes Kemenkes

Tanjungpinang

- apriyandimelly@gmail.co

$m$

\section{Kata Kunci:}

Konsumsi Rumput Laut, Anemia Kehamilan

\section{ABSTRAK}

Anemia kehamilan ditandai dengan kadar hemoglobin yang kurang dari $11 \mathrm{gr} \%$ selama hamil. Peningkatan kejadian anemia sering terjadi pada usia kehamilan trimester III. Untuk mengatasi anemia dibutuhkan jenis makanan alternatif yang membantu dalam sintesis hemoglobin, yaitu rumput laut. Rumput Laut jenis Euchoma $s p$ mengandung zat besi, beberapa senyawa antara yang diperlukan dalam sintesis hemoglobin, memiliki bioavailbilitas zat yang tinggi serta mampu menstabilkan jumlah sel-sel darah merah, sel darah putih, dan hemoglobin. Tujuan penelitian untuk mengetahui status anemia kehamilan sebelum dan sesudah mengkonsumsi rumput laut. Desain penelitian yaitu pre-post test design. Populasi penelitian yaitu ibu hamil trimester III yang ada di Wilayah Kerja Puskesmas Kota Tanjungpinang sebanyak 30 orang. Responden diberikan rumput laut sebanyak 200 gram selama 7 hari dan hari ke-8 dilakukan pengukuran kadar hemoglobin ulang. Setelah diberikan intervensi terjadi peningkatan kadar hemoglobin pada ibu hamil sebesar 1,2gr\% dan tidak ada lagi responden yang menderita anemia kehamilan.

Kata Kunci : konsumsi rumput laut, anemia kehamilan

\begin{abstract}
Anemia in pregnancy is a condition in pregnant women with hemoglobin levels less than 11 gr\% during pregnancy. An increased of anemia often occurs in the third trimester of pregnancy. Pregnant women needs to be supported with nutritional patterns which contain some necessary intermediate in the synthesis of hemoglobin, which is seaweed. Seaweed type Euchoma sp contains iron, a mixture of which is needed in the synthesis of hemoglobin, has a high bioavailability of substances and is able to stabilize the number of red blood cells, white blood cells, and hemoglobin. The purpose of the study was to determine the status of anemia before and after the study. The study design is the pre-post test design. The population of the study was 30 third trimester pregnant women in the Tanjung Pinang City Primary Health Care Work Area. Respondents were given seaweed as much as 200 gram for 7 days and the 8th day repeated hemoglobin levels were measured. After being given an intervention, there was an increase in hemoglobin levels in pregnant women by $1.2 \mathrm{gr} \%$ and there were no more respondents suffering anemia.
\end{abstract}

Keywords : consumption of seaweed, anemia in pregnancy 


\section{PENDAHULUAN}

Pembangunan bidang kesehatan tidak bisa dilepaskan dari upaya mewujudkan kesehatan anak sedini mungkin sejak dalam kandungan. Upaya kesehatan ibu yang dipersiapkan sebelum dan selama kehamilan bertujuan untuk mendapatkan bayi yang sehat. Gangguan kesehatan yang terjadi selama kehamilan dapat memengaruhi kesehatan janin dalam kandungan hingga kelahiran dan pertumbuhan bayi selanjutnya. Selama kehamilan terjadi peningkatan kebutuhan gizi untuk ibu dan janin, sehingga pola makan yang salah pada ibu hamil membawa dampak terhadap terjadinya gangguan gizi, antara lain anemia, pertambahan berat badan yang kurang pada ibu hamil dan gangguan pertumbuhan janin. Salah satu masalah gizi yang banyak terjadi pada ibu hamil adalah anemia gizi. Anemia gizi merupakan masalah gizi mikro terbesar dan tersulit untuk diatasi di seluruh dunia (Setiawan, 2013).

Anemia merupakan penurunan kapasitas darah dalam membawa oksigen yang disebabkan oleh penurunan jumlah sel darah merah dan berkurangnya konsentrasi hemoglobin dalam sirkulasi darah. Anemia kehamilan dapat terjadi karena perubahan normal yang terjadi selama kehamilan.Anemia menjadi masalah kesehatan utama pada negara berkembang dan berhubungan dengan meningkatnya angka kematian ibu dan bayi, persalinan prematur, bayi dengan berat badan lahir rendah dan efek merugikan lainnya. Anemia di Indonesia umumnya disebabkan oleh kekurangan zat besi $(\mathrm{Fe})$ sehingga lebih sering disebut anemia defisiensi besi. World Health Organization (WHO) melaporkan bahwa prevalensi ibu hamil yang mengalami defisiensi besi sekitar 35-75\%. Menurut Riset Kesehatan Dasar (Riskesdas) tahun 2013, kejadian anemia ibu hamil di Indonesia sekitar 37,1\% (Kemenkes RI, 2013).
Anemia dalam kehamilan menurut WHO didefinisikan sebagai kadar hemoglobin yang kurang dari $11 \mathrm{gr} / \mathrm{dl}$ (Husin, 2014). Selama kehamilan akan terjadi peningkatan volume plasma sehingga mengakibatkan hemodilusi atau pengenceran sel darah dan penurunan kadar hemoglobin dari 15 gr/dl menjadi $12,5 \mathrm{gr} / \mathrm{dl}$ dan pada $6 \%$ ibu hamil bisa mencapai di bawah 11 gr/dl. Kebutuhan Fe selama trimester I relatif sedikit yaitu sekitar $0,8 \mathrm{mg}$ sehari yang kemudian meningkat tajam selama trimester II dan III, yaitu $6,3 \mathrm{mg}$ sehari. Hal ini disebabkan karena saat kehamilan terjadi peningkatan volume darah secara progresif mulai minggu ke-6 sampai ke-8 kehamilan dan mencapai puncaknya pada minggu ke-32 sampai ke-34 dan perubahan kecil setelah minggu tersebut (Rizki, 2017).

Salah satu program pemerintah di Indonesia untuk mencegah anemia kehamilan adalah suplementasi besi yang dibagikan gratis melalui Puskesmas dan Posyandu dengan mendistribusikan tablet besi yang mengandung $60 \mathrm{mg}$ elemental besi minimal 90 hari selama kehamilan. Ketidakberhasilan program ini dipengaruhi oleh beberapa faktor, salah satunya yaitu cara mengkonsumsi tablet penambah darah yang tidak tepat baik dari segi waktu maupun cara menggunakan. Hal ini juga didukung dengan data dari Riskesdas (2013) yang menunujukan bahwa cakupan ibu hamil yang mendapatkan tablet besi di Indonesia sekitar $89,1 \%$ dan diantaranya masih ada $33,4 \%$ ibu hamil yang mengonsumsi tablet besi kurang 90 tablet, serta $21,4 \%$ ibu hamil lupa untuk mengkonsumsi tablet besi (Kemenkes RI, 2013).

Peningkatan kandungan zat besi dapat dilakukan dengan memanfaatkan bahan pangan lokal, seperti rumput laut. Rumput laut merupakan salah satu sumber daya hayati yang sangat melimpah di perairan Indonesia yaitu sekitar 8,6\% dari 
total biota di laut. Luas wilayah yang menjadi habitat rumput laut di Indonesia mencapai 1,2 juta hektar atau terbesar di dunia (Suparmi, 2009).

Rumput laut jenis Eucheuma sp merupakan salah satu bahan makanan yang mengandung beberapa senyawa antara yang diperlukan dalam sintesis hemoglobin seperti zat besi, protein dan vitamin B kompleks (Sakinah, 2013). Kadar zat besi yang dimiliki rumput laut kering adalah sekitar 0,5-3,5 mg dalam $100 \mathrm{mg}$ rumput laut. Selain itu, bioavailbilitas zat yang terkandung pada rumput laut lebih tinggi sekitar 2-10\% dibandingkan dengan sayuran, karena kandungan asam fitat dalam rumput laut yang dapat mengganggu absorbsi zat besi sangat sedikit. Eucheuma $s p$ merupakan rumput laut yang dapat menstabilkan jumlah sel-sel darah merah, sel darah putih, dan Hemoglobin. Selain itu, rumput laut berfungsi mengurangi efek samping terhambatnya produksi sel-sel penghasil sel darah (Garcia-Casal, 2008).

\section{METODE}

Ditulis Metode yang digunakan dalam penelitian ini yaitu quasi experiment dengan pre-posttest design. Pengukuran kadar hemoglobin dilakukan dua kali, yaitu sebelum penelitian dan 7 hari setelah diberikan perlakuan. Responden diberikan rumput laut (Euchoma sp) sebanyak 200 gr selama 7 hari. Rumput laut yang diberikan telah diuji laboratorium di PT Saraswanti Indo Genetech (SIG). Variabel penelitian ini meliputi yaitu kadar hemoglobin.

Penelitian ini dilakukan di Wilayah Kerja Puskesmas Kota Tanjungpinang pada bulan September sampai November 2018. Populasi dalam penelitian ini yaitu ibu hamil trimester III, sedangkan sampel yaitu ibu hamil yang memenuhi kriteria dengan jumlah sampel 30 orang. Teknik pengambilan sampel pada penelitian ini dengan cara consecutive sampling, peneliti mengambil semua subyek sesuai kriteria inklusi sampai jumlah subyek minimal terpenuhi. Instrumen yang digunakan adalah lembar isian (checklist). Observasi dilakukan dengan mengunjungi sampel untuk memastikan apakah sampel mengkonsumsi rumput laut (Euchoma $s p$ ) sesuai dengan instruksi. Alat yang digunakan untuk pemeriksaan kadar Hemoglobin $(\mathrm{Hb})$ adalah Easy Touch GCHb.

Uji normalitas yang digunakan adalah uji Shapiro-Wilk, karena jumlah responden dalam penelitian ini kurang dari 50 orang. Analisis data yang digunakan uji nonparametrik yaitu Wilcoxon Signed Rank Test. Penelitian ini telah lulus kaji etik di Komite Etik Poltekkes Jakarta I dengan nomor 163/KEPK/VI/2018.

\section{HASIL DAN PEMBAHASAN HASIL}

Penelitian ini dilakukan selama 3 bulan, yaitu September sampai November 2018. Sebanyak 30 sampel dalam penelitian ini telah memenuhi kriteria inklusi dan eksklusi. Berikut karakteristik responden penelitian:

Tabel 1. Karakteristik Responden

\begin{tabular}{lcc}
\hline $\begin{array}{c}\text { Karakteristik } \\
\text { Responden }\end{array}$ & $\begin{array}{c}\text { Frekuensi } \\
(\mathbf{f})\end{array}$ & $\begin{array}{c}\text { Persentase } \\
(\mathbf{\%})\end{array}$ \\
\hline Umur & & \\
$\quad<20$ tahun dan & & \\
$\quad>35$ tahun \\
$20-35$ tahun & 5 & $16,7 \%$ \\
\hline Paritas & 25 & $83,3 \%$ \\
$\quad$ Primipara & 2 & $6,7 \%$ \\
Multipara & 24 & $80 \%$ \\
$\quad \begin{array}{l}\text { Grande } \\
\text { multipara }\end{array}$ & 4 & $13,3 \%$ \\
\hline Jarak kehamilan & & \\
$<2$ tahun & 4 & $14,2 \%$ \\
\hline
\end{tabular}




\begin{tabular}{ccc}
\hline$\geq 2$ tahun & 24 & $85,7 \%$ \\
\hline Pendidikan & & \\
$<$ SMA & 2 & $6,7 \%$ \\
$\geq$ SMA & 28 & $93,3 \%$ \\
\hline Pekerjaan & & \\
Bekerja & 4 & $13,3 \%$ \\
Tidak Bekerja & 26 & $86,7 \%$ \\
\hline LILA & & \\
$<23,5 \mathrm{~cm}$ & 2 & $6,7 \%$ \\
$\geq 23,5 \mathrm{~cm}$ & 28 & $93,3 \%$ \\
\hline
\end{tabular}

Sumber: Data Primer

Berdasarkan tabel di atas, terlihat bahwa sebagian besar responden berumur 20-35 tahun (83,3\%), sebagain besar ibu multipara $(80 \%)$, rata-rata jarak kehamilan di atas 2 tahun $(85,7 \%)$, sebagian besar berpendidikan SMA dan di atas SMA $(93,3 \%)$, sebagian besar ibu tidak bekerja $(86,7 \%)$ dan hanya 2 orang yang memiliki ukuran LILA di bawah $23,5 \mathrm{~cm}(6,7 \%)$.

Tabel 2. Status Anemia Responden Sebelum dan Setelah Mengkonsumsi Rumput Laut

\begin{tabular}{ccc}
\hline Status & \multicolumn{2}{c}{ Pengukuran Kadar HB } \\
\cline { 2 - 3 } Anemia & Sebelum & Sesudah \\
\hline Anemia & & \\
Tidak & $7(23,3 \%)$ & $0(0 \%)$ \\
Anemia & $24(76,7 \%)$ & $30(100 \%)$ \\
\hline Jumlah & 30 & 30 \\
\hline
\end{tabular}

Berdasarkan tabel di atas, sebanyak 6 orang responden $(25 \%)$ menderita anemia dalam kehamilan, setelah mengkonsumsi rumput laut tidak ada yang menderita anemia.
Tabel 3. Kadar Hemoglobin Responden Sebelum dan Sesudah Mengkonsumsi Rumput laut

\begin{tabular}{cccccc}
\hline $\begin{array}{c}\text { Kadar } \\
\text { Hb }\end{array}$ & $\begin{array}{c}\text { Mean } \\
(\mathbf{g r \%})\end{array}$ & $\begin{array}{c}\text { SD } \\
(\mathbf{g r} \%)\end{array}$ & $\begin{array}{c}\text { Min } \\
(\mathbf{g r} \%)\end{array}$ & $\begin{array}{c}\text { Max } \\
(\mathbf{g r \%})\end{array}$ & $\begin{array}{c}\text { Nilai } \\
\mathbf{p}^{*}\end{array}$ \\
\hline Sebelum & 11,7 & 1,1 & 9,5 & 14,0 & 0,000 \\
Sesudah & 12,9 & 0,8 & 11,0 & 14,6 & \\
\hline
\end{tabular}

Keterangan: * Uji Wilcoxon

Dari tabel di atas, terlihat rata-rata kadar haemoglobin sebelum mengkonsumsi rumput laut sebesar $11,7 \mathrm{gr} \%$, sedangkan setelah mengkonsumsi mengalami peningkatan $12,9 \mathrm{gr} \%$. Selain itu, juga terdapat perbedaan yang bermakna terhadap kadar hemoglobin responden sebelum dan setelah mengkonsumsi rumput laut dengan nilai $\mathrm{p}<0,05(\mathrm{p}=0,000)$.

\section{PEMBAHASAN}

Hemoglobin $(\mathrm{Hb})$ merupakan protein dalam eritrosit yang berfungsi sebagai pengangkat oksigen dari paru-paru ke seluruh tubuh. Hemoglobin juga mengangkut karbondioksida kembali menuju paru-paru untuk dikeluarkan dari tubuh. Pada ibu hamil terjadi peningkatan $30-40 \%$ volume plasma dalam darah, sehingga terjadi pengenceran darah (hemodilusi). Kondisi ini menyebabkan penurunan kadar $\mathrm{Hb}$. Pada ibu hamil dapat menyebabkan keguguran, lahir mati, kelahiran bayi dengan berat badan lahir rendah, perdarahan sebelum dan saat melahirkan, dan kematian ibu (Manuaba, 2010).

Banyak faktor yang dapat
menyebabkan anemia diantaranya umur ibu yang beresiko untuk hamil, jumlah anak yang banyak, jarak kehamilan yang kurang dari 2 tahun, status gizi yang buruk, faktor sosial ekonomi, dan lain-lain. Berdasarkan tabel 1, terlihat bahwa sebagian besar responden tidak memiliki resiko yang tinggi untuk menderita anemia kehamilan, namun ada 
beberapa ibu yang memiliki faktor resiko untuk menderita anemia.

Kebutuhan Fe selama trimester I relatif sedikit yaitu sekitar $0,8 \mathrm{mg}$ sehari yang kemudian meningkat tajam selama trimester II dan III, yaitu 6,3 mg sehari. Hal ini disebabkan karena saat kehamilan terjadi peningkatan volume darah secara progresif mulai minggu ke-6 sampai ke-8 kehamilan dan mencapai puncaknya pada minggu ke-32 sampai ke-34 dan perubahan kecil setelah minggu tersebut. Selama hamil, kebutuhan Fe lebih kurang 1000 mg. Sekitar $500 \mathrm{mg}$ dibutuhkan untuk meningkatkan massa sel darah merah, 300 mg untuk transportasi ke janin dan 200 mg lagi untuk menggantikan cairan yang keluar dari tubuh. Jumlah Fe yang diabsorbsi dari makanan dan cadangan dalam tubuh biasanya tidak mencukupi kebutuhan ibu selama kehamilan sehingga diperlukan penambahan asupan zat besi untuk membantu mengembalikan kadar hemoglobin (Rizki, 2017).

Salah satu upaya mengatasi kejadian anemia dalam kehamilan adalah melalui pemberian suplemen besi oral dan asam folat harian sebanyak $30-60 \mathrm{mg}$ dari unsur besi dan $400 \mathrm{gr}(0,4 \mathrm{mg})$ asam folat. (WHO, 2016). Namun, upaya ini belum berhasil sesuai dengan harapan, sehingga perlu dilakukan peningkatan kandungan zat besi melalui pemanfaatan bahan pangan lokal, seperti rumput laut (Rahmi, 2018; Sakinah, 2013)

Rumput laut jenis Eucheuma $s p$ merupakan salah satu bahan makanan yang mengandung beberapa senyawa antara yang diperlukan dalam sintesis hemoglobin seperti zat besi, protein dan vitamin B kompleks (Sakinah, 2013; Rajapakse, 2011). Kadar zat besi yang dimiliki rumput laut kering adalah sekitar 0,5-35 mg dalam $100 \mathrm{mg}$ rumput laut. Selain itu, bioavailbilitas zat yang terkandung pada rumput laut lebih tinggi sekitar 2-10\% dibandingkan dengan sayuran. Eucheuma $s p$ juga dapat menstabilkan jumlah sel-sel darah merah, sel darah putih, dan Hemoglobin (Rahmi, 2018). Rumput laut juga mengandung vitamin B6 dan B12 yang dibutuhkan dalam sintesis hemoglobin. Vitamin B6 dan asam amino serta glisin pada reaksi awal pembentukan heme. Vitamin B6 dan vitamin B12 diperlukan untuk sintesis globin. Selanjutnya interaksi antara heme dan globin akan menghasilkan hemoglobin (Uluwiyatun, 2014).

Defisiensi zat besi merupakan akibat dari rendahnya bioavabilitas intake zat besi serta peningkatan kebutuhan Fe selama periode kehamilan. Tingginya kadar bioavailbilitas zat yang terkandung pada rumput laut diharapkan dapat mencegah terjadinya defisiensi zat besi. Zat besi merupakan salah satu unsur utama pembentuk hemoglobin sehingga dengan asupan zat besi yang tinggi maka akan menurunkan peluang terjadinya anemia.

Berdasarkan hasil wawancara dengan 7 responden yang menderita anemia $(\% 23,3)$, mereka mengatakan bahwa keluhan seperti pusing dan mudah lelah yang dirasakan sebelum mengkonsumsi rumput laut telah berkurang. Ibu merasa lebih segar dan bersemangat untuk beraktifitas. Hal ini juga ditunjang dari hasil pemeriksaan pada konjunctiva mata ibu yang tidak terlihat pucat. Setelah mengkonsumsi rumput laut selama 7 hari, kadar hemoglobin mengalami peningkatan dan tidak ada yang menderita anemia lagi $(0 \%)$.

Rumput laut yang dikonsumsi selama 7 hari dapat meningkatkan kadar $\mathrm{Hb}$ sebesar 1,2 gr/dl pada ibu hamil, dengan rata-rata $11,7 \mathrm{gr} \%$ sebelum mengkonsumsi rumput laut dan $12,7 \mathrm{gr} \%$ setelah mengkonsumsi rumput laut. Selain itu, juga terdapat perbedaan kadar hemoglobin sebelum dan setelah diberikan rumput laut, dengan nilai $\mathrm{p}<0,05$ $(\mathrm{p}=0,000)$. Hal ini berarti, pemberian 
rumput laut dapat mengatasi masalah anemia kehamilan. Sama halnya dengan penelitian yang dilakukan oleh GarciaCasal (2008), bahwa pemberian rumput laut 7,5 gr perhari dapat memenuhi kebutuhan tubuh akan zat besi serta meningkatkan penyerapan $\mathrm{Fe}$ di dalam tubuh. Penelitian yang dilakukan oleh Uluwiyatun, dkk (2014), melalui pemberian rumput laut selama 7 hari dapat meningkatkan kadar $\mathrm{Hb}$ ibu hamil dengan rata-rata peningkatan kadar $\mathrm{Hb}$ sebesar $11,292 \mathrm{gr} / \mathrm{dl}$.

Hasil penelitian Rahmi dan Nazro (2018) pada ibu hamil anemia, menunjukkan pvalue $\mathrm{p}<0,05$ dengan perubahan mean sebelum diberikan intervensi 8,94 gr/dl menjadi 10,72 gr/dl setelah diberikan intervensi berupa 200 gr rumput laut. Penggunaan rumput laut sebagai salah satu alternatif untuk meningkatkan kadar hb, tidak hanya digunakan bagi ibu hamil saja. Penelitian yang dilakukan oleh Banu dan Mageswari pada tahun 2011, pemberian rumput laut terbukti dapat meningkatkan kadar hemoglobin pada remaja perempuan.

Rumput laut tidak hanya digunakan dalam upaya program kuratif saja, namun dapat sebagai upaya preventif terjadinya anemia pada segala usia, terutama di negara berkembang. Reka, dkk juga menyimpulkan bahwa rumput laut merupakan salah satu sumber daya kehidupan laut yang penting. Rumput laut mengandung banyak mineral, vitamin, asam amino esensial, dan serat makanan, sehingga saat ini banyak dimanfaatkan oleh industri makanan sebagai penguat nutrisi dalam mengatasi kekurangan mikronutrien di dalam masyarakat (Reka, 2017; Mohamed, 2012; Rohani-Ghadikolaei K, 2012). Untuk itu, pemanfaatan rumput laut dapat membantu dalam mencegah dan mengatasi kejadian anemia dalam kehamilan.

\section{SIMPULAN DAN SARAN}

Berdasarkan penelitian ini, dapat disimpulkan bahwa pemberian rumput laut dapat meningkatkan kadar hemoglobin, sehingga mengatasi anemia kehamilan yang terjadi pada responden. Untuk itu, rumput laut dapat dijadikan sebagai salah satu alternatif pencegah terjadinya anemia kehamilan, sehingga perlu pengembangan pembuatan jenis makanan dengan menggunakan bahan dasar rumput laut.

\section{KEPUSTAKAAN}

Garcıa-Casal M.N, Ramirez J, Leets I, Pereira A.C, Quiroga M.F. 2008. Antioxidant Capacity, Polyphenol Content and Iron Bioavailability FromAlgae (UlvaSp., SargassumSp. and PorphyraSp.) in HumanSubjects. British Journal of Nutrition. Vol. 101 Juli 2008 Hal. 79-85.

Handayani P, Wahyu, Novayelinda R, Jumaini. 2014. Hubungan Status Gizi Dengan Kejadian Anemia pada Remaja Putri. JOM.;2(1).

Husin F. 2014. Asuhan Kehamilan Berbasis Bukti. Jakarta: Sagung Seto.

Kemenkes RI. 2013. Laporan hasil Riset Kesehatan Dasar (Riskesdas) tahun 2013. Jakarta: Badan Penelitian dan Pengembangan Kesehatan Kementerian Kesehatan RI.

Manuaba I.B.G. 2010. Ilmu Kebidanan, Penyakit Kandungan dan KB. Jakarta: EGC.

Mohamed S., Hsyim S.N., Rahman H.A. Seaweeds: A Suistainable Functional Food for Complementary and Alternative Therapy. Trend in Food Science and Technology. Vol. 23. 2012. Hal. 83-96.

Rahmi R, Nazro Z. 2018. Efektifitas Konsumsi Rumput Laut untuk Meningkatkan Kadar Haemoglobin pada Ibu Hamil Anemia. Jurnal 
Endurance. Vol. 3 No. 1 Februari 2018 Hal. 195-199.

Rajapakse N, Kim S-J. 2011. Nutritional and Digestive Health Benefits of Seaweed. Advances in Food and Nurtritional Research. Vol.64. Desember 2011. Hal 17-28.

Reka P., Thahira B.A., Seethalakshmi M., Elemental Compositio of Selected Edible Seaweeds Using SEMEnergy Dispersive Spectroscopic Analysis. International Food Research Journal. Vol. 24. No. 2. April 2017. Hal 600-6.

Rizki F, Lipoeto NI, Ali H. 2017. Hubungan Suplementasi Tablet $\mathrm{Fe}$ dengan Kadar Hemoglobin pada Ibu Hamil Trimester III di Puskesmas Air Dingin Kota Padang. Jurnal Kesehatan Andalas. Vol. 6 No. 3 Hal. 502-506.

Rohani-Ghadikolaei K., Abdullah E., Ng WK. Evaluation of the Proximate, Fatty acid and Mineral Composition of Representative Green, Brown, and Red Seaweeds from the Persian Gulf of Iran as Potential Food and Feed Resources. J. Food Sci Technol. Vol. 49. No, 6. Desember 2012. Hal 77480.

Sakinah N, Ayustaningwarno F. 2013. Pengaruh Substitusi Tepung Terigu dengan tepung Rumput Laut Sargassum $S p$ terhadap Kandungan Zat Gizi dan Kesukaan MP-ASI
Biskuit Kaya Zat Besi. Journal of Nutrition College. Vol. 2 No. 12013 Hal. 154-161.

Setiawan A, Lipoeto N.I, Izzah A.Z. 2013. Hubungan Kadar Hemoglobin Ibu Hamil Trimester III Dengan Berat Bayi Lahir di Kota Pariaman. Jurnal Kesehatan Andalas. Vol. 2 No. 1 Hal. 34-37.

Suparmi, Sahri A. 2009. Mengenal Potensi

Rumput Laut : Kajian Pemanfaatan

Sumber Daya Rumput Laut dari Aspek Industri dan Kesehatan. Sultan Agung Vol. XLIV No. 118 Agustus 2009 Hal. 82-116.

Uluwiyatun, Runjati, Suwondo A. 2014. Pengaruh Konsumsi Rumput Laut (Euchoma Sp) terhadap Peningkatan Kadar Hemoglobin dan Status Fe Ibu Hamil Anemia di Kabupaten Pekalongan. Jurnal Kebidanan. Vol. 3 No. 7 Oktober 2014 Hal. 8-15.

Yuniarti A. 2011. Kadar Zat Besi, Serat, Gula Total, dan Daya Terima Permen Jelly dengan Penambahan Rumput Laut Gracilaria $S p$ dan Sargassum Sp. Program Studi Ilmu Gizi Fakultas Kedokteran Universitas Diponegoro. Semarang. Yuniarti A, Hadisaputro S, Suci N. 2016. Pengaruh pemberian rumput laut sargassum sp terhadap kadar hemoglobin dan feritin serum. Vol. 5, No. 1 Desember 2016 Hal. 7-13. 